\title{
PENGARUH EKSTRAK DAUN KEMBANG BULAN (Tithonia diversifolia A.Gray) TERHADAP KADAR GLUKOSA DARAH TIKUS PUTIH WISTAR YANG DIINDUKSI OLEH ALOXAN
}

\author{
Anna Pradiningsih ${ }^{*}$, Siti Pandanwangi Tw², Aribowo ${ }^{3}$ \\ 1,3 Sekolah Tinggi Farmasi YPIB Cirebon \\ ${ }^{2}$ Akademi Farmasi Muhamadiyah Cirebon \\ *Korespondensi: Jl. Perjuangan Majasem Cirebon, Email: annapradiningsih@gmail.com
}

\begin{abstract}
ABSTRAK
Latar Belakang : Diabetes melitus menjadi masalah kesehatan utama karena komplikasinya bersifat jangka pendek dan panjang. Tumbuhan yang digunakan untuk pengobatan diabetes, salah satunya adalah daun Kembang Bulan (Tithonia diversifolia A.Gray). Daun Kembang Bulan digunakan sebagai anti diabetes dengan kandungan zat aktif senyawa seskuiterpen,1 $\beta-$ hydroxydiversifolin-3-0-metil eter dan 1 $\beta$-hydroxytirotundin-3-0-metil eter, yang diisolasi dari bagian aerial-semua bagian tanaman kecuali akar Kembang Bulan (Tithonia diversifolia).

Tujuan : Mengetahui apakah daun Kembang Bulan (Tithonia diversifolia A.Gray) memiliki pengaruh terhadap kadar glukosa tikus yang diinduksi aloxan, mengetahui pada dosis berapakah yang lebih efektif memiliki pengaruh penurunan glukosa tikus dan mengetahui kestabilan formulasi suspensi daun Kembang Bulan (Tithonia diversifolia A.Gray).

Metode : Metode penelitian yang digunakan adalah metode eksperimen. Suspensi ekstrak dibuat dengan tiga dosis, yaitu $200 \mathrm{mg} / \mathrm{kgBB}, 300 \mathrm{mg} / \mathrm{kgBB}$, dan $400 \mathrm{mg} / \mathrm{kgBB}$ yang dilakukan pada 15 ekor tikus jantan yang diinduksikan aloxan.

Hasil : Berdasarkan hasil pengukuran penurunan kadar glukosa darah pada tikus putih jantan setelah perlakuan selama 21 hari dapat diketahui bahwa suspensi ekstrak daun Kembang Bulan pada dosis $200 \mathrm{mg} / \mathrm{kgBB}, 300 \mathrm{mg} / \mathrm{kgBB}$, dan $400 \mathrm{mg} / \mathrm{kgBB}$ menghansilkan presentase penurunan sebesar 44\%, 62,3\% dan 63,2\%. Pada Kontrol Positif yaitu Acarbose yang disuspensikan dengan dosis $9 \mathrm{mg} / \mathrm{kgBB}$ didapat presentase penurunan sebesar $57 \%$. Pada Kontrol Negatif yaitu suspensi CMC 1\% menghasilkan presentase kenaikan sebesar 15,7\%. Hasil analisa data dengan uji $\mathrm{T}$ test menyatakan bahwa tidak ada perbedaan signifikan diantara ketiga dosis dengan control positif.

Simpulan : Dosis yang efektif adalah dosis dengan presentase terendah yaitu $200 \mathrm{~m} / \mathrm{kgBB}$. Stabilitas suspensi ekstrak Daun Kembang Bulan (Tithonia diversifolia A.Gray) pada dosis 200 $\mathrm{mg} / \mathrm{kgBB}, 300 \mathrm{mg} / \mathrm{kgBB}$, dan $400 \mathrm{mg} / \mathrm{kgBB}$, kontrol positif dan kontrol negatif relatif stabil pada suhu $0^{\circ} \mathrm{C}, 25^{\circ} \mathrm{C}$ dan $50^{\circ} \mathrm{C}$.
\end{abstract}

Kata kunci : Daun Kembang Bulan (Tithonia diversifolia A.Gray),diabetes mellitus, suspense, aloxan

\footnotetext{
ABSTRACT

Background: Diabetes mellitus becomes a major health problem because its complications are short and long term. Plants used for the treatment of diabetes, one of which is Daun Kembang Bulan (Tithonia diversifolia A.Gray). Daun Kembang Bulan (Tithonia diversifolia A.Gray) is used as an anti-diabetic with the active substance of sesquiterpene compound, $1 \beta$-hydroxydiversifolin-3-Omethyl ether and 1 $\beta$-hydroxytirotundine-3-0-methyl ether, isolated from the aerial part-all parts of the plant except root of Kembang Bulan (Tithonia diversifolia A.Gray)

Objective: To find out whether the Daun Kembang Bulan (Tithonia diversifolia A.Gray) had an effect on aloxan-induced glucose levels of rats, knowing which doses were more effective had a decreasing effect on rat glucose and on the stability of the leaf-bloom formulation of Daun Kembang Bulan (Tithonia diversifolia A.Gray)

Method: The research method used is experimental method. The extract suspension was prepared with three doses, $200 \mathrm{mg} / \mathrm{kgBB}, 300 \mathrm{mg} / \mathrm{kgBB}$, dan $400 \mathrm{mg} / \mathrm{kgBB}$ performed on 15 male rats induced aloxan.
} 
Result: Based on the result of measurement of the decrease of blood glucose level on male white rats after 21 days treatment can be seen that the suspension of Daun Kembang Bulan (Tithonia diversifolia A.Gray) extract at dose $200 \mathrm{mg} / \mathrm{kgBB}, 300 \mathrm{mg} / \mathrm{kgBB}$, and $400 \mathrm{mg} / \mathrm{kgBB}$ obtained percentage decrease equal to 44\%, 62.3\% and 63.2\%. On the Positive Control of Acarbose suspended with a dose of $9 \mathrm{mg} / \mathrm{kgBB}$ obtained percentage decrease of 57\%. On Negative Control the 1\% CMC suspension yields an increase percentage of 15.7\%. The result of data analysis with $T$ test test stated that there was no significant difference between the three doses with positive control.

Conclusion: The effective dose is the dose with the lowest percentage of $200 \mathrm{mg} / \mathrm{kgBB}$. The suspension stability of Daun Kembang Bulan (Tithonia diversifolia A.Gray) extract at doses of $200 \mathrm{mg} / \mathrm{kgBB}, 300 \mathrm{mg} / \mathrm{kgBB}$ dan $400 \mathrm{mg} / \mathrm{kgBB}$, positive control and negative control is relatively stable at temperatures of $0^{\circ} \mathrm{C}, 25^{\circ} \mathrm{C}$ and $50^{\circ} \mathrm{C}$.

Keywords: Daun Kembang Bulan (Tithonia diversifolia A.Gray), diabetes mellitus, suspense, aloxan

\section{PENDAHULUAN}

Penderita diabetes mellitus pada tahun 2000 diperkirakan sekitar 150 juta orang di dunia menderita diabetes mellitus. Jumlah ini diperkirakan akan meningkat menjadi dua kali lipat pada tahun 2005. Peningkatan itu terjadi di Negara berkembang seperti Indonesia (1). Populasi penderita diabetes mellitus di Indonesia diperkirakan berkisar antara $1,5 \%$ sampai $2,5 \%{ }^{(1)}$.

Diabetes melitus merupakan suatu penyakit atau gangguan metabolisme kronik yang ditandai dengan tingginya kadar gula dalam darah disertai adanya gangguan metabolism karbohidrat, lipid dan protein sebagai akibat dari adanya insufisiensi insulin. Insufisiensi insulin terjadi disebabkan kurang responsifnya sel-sel tubuh terhadap insulin (2).

Diabetes merupakan kondisi kronis yang ditandai dengan peningkatan konsentrasi gula darah disertai munculnya gejala utama yang khas, yakini urine yang berasa manis dalam jumlah yang besar atau biasa disebut kencing manis. Kelainan yang menjadi penyebab dasar terjadinya diabetes melitus adalah defisiensi relatif atau absolut dari hormon insulin yang dapat menurunkan kadar gula dalam darah (3).

Permasalahan tersebut diatas akan bertambah besar bila tidak ada upaya untuk pengobatan dan pencegahan. Pada zaman moderen ini telah dikembangkan obatobatan kimia guna untuk pengobatan diabetes melitus, tetapi terdapat banyak kerugian berupa efek samping obat dan harganya yang mahal. Dalam beberapa tahun belakangan banyak digunakan bahan alam dalam pengobatan untuk melengkapi ataupun mengganti terapi obat kimia. Pada kasus diabetes melitus, penelitian yang telah dilakukan menunjukkan bahwa banyak ekstrak tumbuhan yang efektif untuk menurunkan kadar gula darah dengan efek samping lebih rendah dan harga yang lebih murah dibanding obat anti diabetik biasanya.

Tumbuhan yang digunakan untuk pengobatan diabetes, salah satunya adalah daun Kembang Bulan (Tithonia diversifolia A.Gray). Daun Kembang Bulan digunakan sebagai anti diabet karena mengandung tiga jenis senyawa seskuiterpen, $1 \beta$ hydroxydiversifolin-3-0-metil eter dan $1 \beta$ hydroxytirotundin-3-0-metil eter, yang diisolasi dari bagian aerial-semua bagian tanaman kecuali akar Kembang Bulan (Tithonia diversifolia) terbukti mampu menurunkan kadar gula secara signifikan. Kembang Bulan juga mengandung senyawa flavonoid, alkaloid, tanin dan saponin yang mampu untuk menurunkan kadar gula darah (4). Penelitian mengacu pada dosis yang dilakukan pada penelitian (Ronald Pasaribu dkk,2015) yaitu $14 \mathrm{mg} / \mathrm{kgBB}, 42 \mathrm{mg} / \mathrm{kgBB}$, dan $70 \mathrm{mg} / \mathrm{kgBB}$ pada mencit yang bila dikonversi ke tikus yaitu $98, \mathrm{mg} / \mathrm{kgBB}$, $294 \mathrm{mg} / \mathrm{kgBB}$, dan 490mg/kgBB. Dosis efektif yaitu $14 \mathrm{mg} / \mathrm{kgBB}$.

\section{METODE}

Metode penelitian yang digunakan adalah metode eksperimen. Populasi dalam penelitian ini adalah tanaman Kembang Bulan (Tithonia diversifolia A.Gray) dan tikus. Sampel akan diambil pada penelitian ini adalah bagian daun dari tumbuhan kembang 
bulan(Tithonia diversifolia A.Gray) dan tikus putih jantan galur wistar.

Alat-alatyang digunakan dalam penelitian

Timbangan analitik, gelas ukur, spuit, oral sonde, maserator, batang pengaduk, kain flanel, pipet tetes, mortir dan stamper dan vial.

\section{Bahan-bahan yang digunakan dalam penelitian}

Daun Kembang Bulan(Tithonia diversifolia A.Gray), Etanol 70\%, Aloksan, Acarbose yang disuspensi, Aquadest steril, Nipagin, Na-CMC, Aqua pro Na-CMC.

\section{Pembuatan Ekstrak Daun Kembang Bulan}

Memasukan kedalam maserator simplisia daun Kembang Bulan yang telah dihaluskan sebanyak 250 gr. Tambahkan etanol $70 \%$ sampai 75 bagian. Biarkan rendaman \pm 5 hari sambilsesering mungkin diaduk, dan harus terlindung dari sinar matahari. Setelah 5 hari keluarkan maserat, disaring menggunkan kain flanel agar terpisah dari ampasnya dan ditampung dibeaker glass, ukur volume maserat (filtrat 1). Kemudian ampas dimasukan kedalam maserator, dan ditambahkan etanol $70 \%$ sampai 100 bagiannya biarkan selama 2 hari sambil diaduk sesering mungkin. Setelah 2 hari keluarkan maserat dari maserator saring menggunakan kain flanel (filtrat 2). Kemudian filtrat 1 dan filtrat 2 digabungkan dan ukur volume. Masukan kedalam cawan penguap dan diuapkan hingga memperoleh ekstrak kental.

\section{Pembuatan Suspensi}

Suspensi ekstrak dibuat dengan tiga dosis, yaitu $40 \mathrm{mg} / 200 \mathrm{grBB}$ tikus, $60 \mathrm{mg} / 200 \mathrm{grBB}$ tikus, dan $80 \mathrm{mg} / 200 \mathrm{grBB}$ tikus. Suspending agent yang digunakan yaitu Natrium CMC1\%, dan total tiap sediaan sebanyak $200 \mathrm{ml}$.

Tabel 1. Formulasi Suspensi Dengan Berbagai Dosis

\begin{tabular}{|c|c|c|c|}
\hline Formulasi & $\begin{array}{c}\text { Dosis } 200 \mathrm{mg} / \mathrm{KgBB} \\
(40 \mathrm{mg} / 200 \mathrm{gr})\end{array}$ & $\begin{array}{c}\text { Dosis } 300 \mathrm{mg} / \mathrm{KgBB} \\
\text { (60 mg/200 gr) }\end{array}$ & $\begin{array}{c}\text { Dosis } 400 \mathrm{mg} / \mathrm{KgBB} \\
\text { (80 mg/200 gr) }\end{array}$ \\
\hline $\begin{array}{l}\text { R/ Ekstrak Daun } \\
\text { Kembang Bulan }\end{array}$ & $4 \mathrm{~g}$ & $6 \mathrm{~g}$ & $8 \mathrm{~g}$ \\
\hline $\mathrm{CMC}$ & $1 \%$ & $1 \%$ & $1 \%$ \\
\hline Nipagin & $0,1 \%$ & $0,1 \%$ & $0,1 \%$ \\
\hline Aqua & $\mathrm{Ad} 200 \mathrm{ml}$ & $\mathrm{Ad} 200 \mathrm{ml}$ & $\mathrm{Ad} 200 \mathrm{ml}$ \\
\hline
\end{tabular}

Timbang semua bahan. Membuat corpus dengan mencampurkan CMC dengan aqua pro CMC di dalam mortir, campur hingga melarut. Masukkan Ekstrak Daun Yakon dalam mortir, gerus sampai homogen.Tambahkan Nipagin, gerus sampai homogen. Encerkan dengan aquadest, masukkan ke dalam botol. Masukkan ke dalam botol, tambahkan aqua sampai $200 \mathrm{ml}$. Tutup botol kemudian dikocok.

\section{Uji Stabiitas Suspensi Daun Kembang Bulan}

Stabilitas suspensi daun kembang bulan (Tithonia diversifolia A.Gray) dengan dosis 40mg/200grBB tikus, 60mg/200grBB tikus, dan $80 \mathrm{mg} / 200 \mathrm{grBB}$ yang telah dibuat, diuji stabilitasnya dengan parameter bentuk, bau, warna, $\mathrm{pH}$, dan viskositas pada suhu 0 ${ }^{\circ} \mathrm{C}, 25{ }^{\circ} \mathrm{C}$, dan $50{ }^{\circ} \mathrm{C}$ pada hari ke $1,8,15,22$, dan 29.

\section{Pembuatan Pengenceran Aloksan}

Pemberian volume larutan maksimal secara intravena pada tikus $100 \mathrm{gr}$ adalah 1 ml (Harmita, 2008). Berat rata-rata tikus yang digunakan dalam penelitian ini adalah 200 gr. Jadi $200 / 100 \times 1=2 \mathrm{ml}$.

Dosis yang akan diinduksikan dalam penelitian ini adalah $135 \mathrm{mg} / \mathrm{kg}$ BB. Berat badan tikus yang digunakan rata-rata adalah 200 gr.

Perhitungan pengenceran aloksan :

$=135 \mathrm{mg} \times \frac{200 \mathrm{gr}}{1 \mathrm{~kg}}$

$=135 \mathrm{mg} \times \frac{200 \mathrm{gr}}{1000 \mathrm{gr}}$

$=27 \mathrm{mg} / 0,5 \mathrm{ml}$

Untuk jumlah tikus 15 ekor :

Aloksan yang diperlukan : $27 \times 15=405 \mathrm{mg}$

Aquadest yang diperlukan: $0,5 \mathrm{ml} \times 15=7,5$ $\mathrm{ml}$

\section{Pembuatan Dosis untuk Obat Acarbose} Dosis yang di pakai berdasarkan dosis manusia yang di konversikan dengan 
dosis hewan (tikus), faktor konversi untuk manusia dengan berat badan $70 \mathrm{~kg}$ pada tikus dengan berat badan 200 gr adalah 0,018. (Harmita, 2008). Diketahui bahwa dosis metformin untuk 1 kali minum pada manusia dengan berat badan $70 \mathrm{~kg}$ adalah 500 mg. Perhitungannya adalah sebagai berikut :

Untuk manusia $70 \mathrm{~kg}=100 \mathrm{mg}$

Untuk tikus $200 \mathrm{~g}=100 \mathrm{mg} \times 0,018$

$$
=1,8 \mathrm{mg}
$$

$=1,8 \mathrm{mg} / 200$ gr Tikus $\approx 9 \mathrm{mg} / \mathrm{kg} \mathrm{BB}$

Untuk membuat suspensi acarbose $200 \mathrm{ml} \mathrm{(2}$ ml untuk 1 kali minum), perhitungan penimbangan metforminnya adalah :

$\frac{200 \mathrm{ml}}{2 \mathrm{ml}} \times 1,8 \mathrm{mg}=180 \mathrm{mg} \sim 0,18 \mathrm{gr}$

\section{Pembuatan Larutan CMC 1\%}

Masukkan 2 gr CMC dan $40 \mathrm{ml}$ aqua pro CMC ke dalam lumpang, aduk dan gerus sampai mengembang, encerkan dengan aquadest sampai $200 \mathrm{ml}$.

\section{Pengujian Hewan Uji}

Menyediakan 15 ekor tikus. Membagi 15 ekor tikus menjadi 5 kelompok, masingmasing kelompok terdiri dari 3 ekor tikus. Tikus jantan (hewan uji) terlebih dahulu dipuasakan diukur kadar gula darahnya sebelum diinduksi Aloxan. Semua kelompok hewan uji diinduksi Aloxan sebanyak 0,5ml secara intravena. Kemudian sekitar 8-12 jam setelah diinduksi aloksan, masing-masing tikus diberi larutan glukosa 10\% sebanyak 2 ml. Hari ke-2 setelah tikus diinduksi, ukur kembali kadar gula darahnya, tikus dengan kadar darah diatas $200 \mathrm{mg} /$ dl. Kelompok I, II, dan III diberi sampel uji suspensi ekstrak daun kembang bulan masing-masing dengan dosis $40 \mathrm{mg} / 200 \mathrm{grBB}$ tikus, $60 \mathrm{mg} / 200 \mathrm{grBB}$ tikus, dan $80 \mathrm{mg} / 200 \mathrm{grBB}$ secara oral sebanyak $2 \mathrm{ml}$. Kelompok IV sebagai kontrol positif diberi suspensi Metformin $\mathrm{HCl}$ secara oral sebanyak $2 \mathrm{ml}$. Kelompok $\mathrm{V}$ sebagai kontrol negatif diberi suspensi CMC secara oral sebanyak $2 \mathrm{ml}$. Masing-masing hewan uji setelah perlakuan diukur kembali kadar gula darahnya setiap 7 hari setelah diberi pengobatan selama 21 hari.

HASIL

\section{Hasil Determinasi}

Determinasi tanaman dilakukan di Laboratorium ITB Bandung, hasil determinasi menyatakan bahwa simplisia yang diperiksa benar merupakan Kembang Bulan (Tithonia diversifolia A.Gray).

\section{Hasil Ekstrak daun Kembang Bulan}

Hasil ekstrak daun Kembang Bulan 250 gram dan Alkohol $75 \% 2500$ ml, didapat ekstrak cair sebanyak $1700 \mathrm{ml}$, kemudian diuapkan hingga didapat ekstrak kental sebanyak 70 gram dengan hasil rendemen $4 \%$.

\section{Hasil Uji Stabilitas Sediaan}

Uji stabilitas sediaan suspensi daun Kembang Bulan (Tithonia diversifolia A.Gray) dilakukan selama 29 hari dengan perlakuan pada suhu $0{ }^{\circ} \mathrm{C}, 25^{\circ} \mathrm{C}$ dan $50^{\circ} \mathrm{C}$.

Tabel 2. Data Pengamatan Hasil Evaluasi Sediaan

\begin{tabular}{ccccccc}
\hline \multirow{2}{*}{ Sampel } & \multicolumn{5}{c}{ Evaluasi Sediaan Suspensi } \\
\cline { 2 - 6 } & Bau & Bentuk & Warna & pH & Kekentalan & Sedimentasi \\
\cline { 2 - 6 } $\mathbf{X}_{\mathbf{1}}$ & Bau Khas & Cair & Coklat Muda & 5 & 1,18 & - \\
\hline $\mathbf{X}_{\mathbf{2}}$ & Bau Khas & Kental & Coklat Muda & 5 & 2,30 & - \\
\hline $\mathbf{X}_{\mathbf{3}}$ & Bau Khas & Kental & Coklat Tua & 5 & 2.89 & \\
\hline $\mathbf{K}+$ & $\begin{array}{c}\text { Tidak } \\
\text { Berbau }\end{array}$ & Kental & $\begin{array}{c}\text { Bening tidak } \\
\text { berwarna }\end{array}$ & 7 & 1,69 & - \\
\hline K- & $\begin{array}{c}\text { Tidak } \\
\text { Berbau }\end{array}$ & Kental & $\begin{array}{c}\text { Bening tidak } \\
\text { berwarna }\end{array}$ & 7 & 1,47 & - \\
\hline
\end{tabular}

Berdasarkan hasil evaluasi suspensi ekstrak daun Kembang Bulan pada suhu kamar memiliki bentuk cair hingga kental dengan warna coklat muda dengan pH 5 yang bersifat asam lemah.

Hasil uji stabilitas suspensi 
Pemeriksaan organoleptis yang warna. dilakukan meliputi rasa, bau, bentuk dan

Tabel 3. Hasil Uji Organoleptis Bentuk Pada Suhu $0^{\circ} \mathrm{C}$

\begin{tabular}{|c|c|c|c|c|c|}
\hline \multirow{2}{*}{ Sampel } & \multirow{2}{*}{$\begin{array}{l}\text { Karakterisasi } \\
\text { yang diamati }\end{array}$} & \multicolumn{4}{|c|}{ 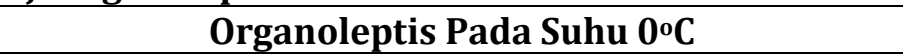 } \\
\hline & & Hari ke -8 & Hari ke -15 & Hari ke -22 & Hari ke -29 \\
\hline \multirow{3}{*}{$\mathbf{X}_{1}$} & Bau & Bau khas & Bau khas & Bau khas & Bau khas \\
\hline & Warna & $\begin{array}{l}\text { Coklat } \\
\text { muda }\end{array}$ & $\begin{array}{l}\text { Coklat } \\
\text { muda }\end{array}$ & Coklat muda & $\begin{array}{l}\text { Coklat } \\
\text { muda }\end{array}$ \\
\hline & Bentuk & Cairan & Cairan & Cairan & Cairan \\
\hline \multirow{3}{*}{$\mathbf{X}_{2}$} & Bau & Bau khas & Bau khas & Bau khas & Bau khas \\
\hline & Warna & $\begin{array}{l}\text { Coklat } \\
\text { muda }\end{array}$ & $\begin{array}{l}\text { Coklat } \\
\text { muda }\end{array}$ & Coklat muda & $\begin{array}{l}\text { Coklat } \\
\text { keruh }\end{array}$ \\
\hline & Bentuk & Cairan & Cairan & $\begin{array}{l}\text { Cairan } \\
\text { Kental }\end{array}$ & $\begin{array}{l}\text { Cairan } \\
\text { Kental }\end{array}$ \\
\hline \multirow{3}{*}{$\mathbf{X}_{3}$} & Bau & Bau khas & Bau khas & Bau khas & Bau khas \\
\hline & Warna & $\begin{array}{l}\text { Coklat } \\
\text { keruh }\end{array}$ & $\begin{array}{l}\text { Coklat } \\
\text { keruh }\end{array}$ & Coklat tua & Coklat tua \\
\hline & Bentuk & Kental & Kental & Kental & Kental \\
\hline \multirow{3}{*}{$\mathbf{K +}$} & Bau & Bau khas & Bau khas & $\begin{array}{c}\text { Tidak } \\
\text { berbau }\end{array}$ & $\begin{array}{c}\text { Tidak } \\
\text { berbau }\end{array}$ \\
\hline & Warna & $\begin{array}{c}\text { Bening } \\
\text { tidak } \\
\text { berwarna }\end{array}$ & $\begin{array}{c}\text { Bening } \\
\text { tidak } \\
\text { berwarna }\end{array}$ & $\begin{array}{l}\text { Bening tidak } \\
\text { berwarna }\end{array}$ & $\begin{array}{c}\text { Bening } \\
\text { tidak } \\
\text { berwarna }\end{array}$ \\
\hline & Bentuk & Kental & Kental & Kental & Kental \\
\hline \multirow{3}{*}{ K- } & Bau & $\begin{array}{c}\text { Tidak } \\
\text { berbau }\end{array}$ & $\begin{array}{c}\text { Tidak } \\
\text { berbau }\end{array}$ & $\begin{array}{c}\text { Tidak } \\
\text { berbau }\end{array}$ & $\begin{array}{c}\text { Tidak } \\
\text { berbau }\end{array}$ \\
\hline & Warna & $\begin{array}{c}\text { Bening } \\
\text { tidak } \\
\text { berwarna }\end{array}$ & $\begin{array}{c}\text { Bening } \\
\text { tidak } \\
\text { berwarna }\end{array}$ & $\begin{array}{l}\text { Bening tidak } \\
\text { berwarna }\end{array}$ & $\begin{array}{c}\text { Bening } \\
\text { tidak } \\
\text { berwarna }\end{array}$ \\
\hline & Bentuk & Cairan & Cairan & Kental & Kental \\
\hline
\end{tabular}

Tabel 4. Hasil Uji Organoleptis Bentuk Pada Suhu $25^{\circ} \mathrm{C}$

\begin{tabular}{|c|c|c|c|c|c|}
\hline \multirow{2}{*}{ Sampel } & \multirow{2}{*}{$\begin{array}{l}\text { Karakterisasi } \\
\text { yang diamati }\end{array}$} & \multicolumn{4}{|c|}{ Organoleptis Pada Suhu $25^{\circ} \mathrm{C}$} \\
\hline & & Hari ke -8 & Hari ke -15 & Hari ke -22 & Hari ke -29 \\
\hline \multirow{3}{*}{$\mathbf{X}_{1}$} & Bau & Bau khas & Bau khas & Bau khas & Bau khas \\
\hline & Warna & $\begin{array}{l}\text { Coklat } \\
\text { muda }\end{array}$ & $\begin{array}{l}\text { Coklat } \\
\text { muda }\end{array}$ & Coklat muda & $\begin{array}{c}\text { Coklat } \\
\text { muda keruh }\end{array}$ \\
\hline & Bentuk & Cairan & Cairan & Cairan & Cairan \\
\hline \multirow{3}{*}{$\mathbf{X}_{2}$} & Bau & Bau khas & Bau khas & Bau khas & Bau khas \\
\hline & Warna & $\begin{array}{l}\text { Coklat } \\
\text { muda }\end{array}$ & $\begin{array}{l}\text { Coklat } \\
\text { muda }\end{array}$ & Coklat muda & $\begin{array}{l}\text { Coklat } \\
\text { muda, }\end{array}$ \\
\hline & Bentuk & Cairan & Cairan & Cairan & Cairan, \\
\hline \multirow{3}{*}{$\mathbf{X}_{3}$} & Bau & Bau khas & Bau khas & Bau khas & Bau khas \\
\hline & Warna & $\begin{array}{l}\text { Coklat } \\
\text { keruh }\end{array}$ & Coklat tua & Coklat tua & Coklat tua \\
\hline & Bentuk & Kental & Kental & Kental & Kental \\
\hline \multirow[b]{2}{*}{ K+ } & Bau & Bau khas & $\begin{array}{l}\text { Tidak } \\
\text { berbau }\end{array}$ & $\begin{array}{l}\text { Tidak } \\
\text { berbau }\end{array}$ & $\begin{array}{l}\text { Tidak } \\
\text { berbau }\end{array}$ \\
\hline & Warna & $\begin{array}{c}\text { Bening } \\
\text { tidak } \\
\text { berwarna }\end{array}$ & $\begin{array}{c}\text { Bening } \\
\text { tidak } \\
\text { berwarna }\end{array}$ & $\begin{array}{c}\text { Bening tidak } \\
\text { berwarna }\end{array}$ & $\begin{array}{c}\text { Bening } \\
\text { tidak } \\
\text { berwarna }\end{array}$ \\
\hline
\end{tabular}


Journal of Holistic and Health Sciences

Vol.1, No.2, Juli-Dese mber $2017 \mid \mathbf{1 3 8}$

\begin{tabular}{cccccc}
\hline & Bentuk & Kental & Kental & Kental & Kental \\
\hline & \multirow{2}{*}{ Bau } & $\begin{array}{c}\text { Tidak } \\
\text { berbau }\end{array}$ & $\begin{array}{c}\text { Tidak } \\
\text { berbau }\end{array}$ & $\begin{array}{c}\text { Tidak } \\
\text { berbau }\end{array}$ & $\begin{array}{c}\text { Tidak } \\
\text { berbau }\end{array}$ \\
\cline { 2 - 6 } K- & Warna & $\begin{array}{c}\text { Bening } \\
\text { tidak } \\
\text { berwarna }\end{array}$ & $\begin{array}{c}\text { Bening } \\
\text { tidak } \\
\text { berwarna }\end{array}$ & $\begin{array}{c}\text { Bening tidak } \\
\text { berwarna }\end{array}$ & $\begin{array}{c}\text { Bening } \\
\text { tidak } \\
\text { berwarna }\end{array}$ \\
\cline { 2 - 6 } & Bentuk & Kental & Kental & Kental & Kental \\
\hline
\end{tabular}

Tabel 5. Hasil Uji Organoleptis Bentuk Pada Suhu 50॰C

\begin{tabular}{|c|c|c|c|c|c|}
\hline \multirow{2}{*}{ Sampel } & \multirow{2}{*}{$\begin{array}{l}\text { Karakterisasi } \\
\text { yang diamati }\end{array}$} & \multicolumn{4}{|c|}{ Organoleptis Pada Suhu $5^{\circ} \mathrm{C}$} \\
\hline & & Hari ke -8 & Hari ke -15 & Hari ke -22 & Hari ke -29 \\
\hline \multirow{3}{*}{$\mathbf{X}_{1}$} & Bau & Bau khas & Bau khas & Bau khas & Bau khas \\
\hline & Warna & $\begin{array}{l}\text { Coklat } \\
\text { muda }\end{array}$ & Coklat muda & $\begin{array}{l}\text { Coklat muda } \\
\text { keruh }\end{array}$ & $\begin{array}{l}\text { Coklat muda } \\
\text { keruh }\end{array}$ \\
\hline & Bentuk & Cairan & Cairan & Cairan & Cairan \\
\hline \multirow{3}{*}{$\mathbf{X}_{2}$} & Bau & Bau khas & Bau khas & Bau khas & Bau khas \\
\hline & Warna & $\begin{array}{l}\text { Coklat } \\
\text { muda }\end{array}$ & Coklat tua & $\begin{array}{c}\text { Coklat tua } \\
\text { keruh }\end{array}$ & $\begin{array}{l}\text { Coklat tua } \\
\text { keruh }\end{array}$ \\
\hline & Bentuk & Cairan, & Kental & Kental & Kental \\
\hline \multirow{3}{*}{$\mathbf{X}_{3}$} & Bau & Bau khas & Bau khas & Bau khas & Bau khas \\
\hline & Warna & Coklat tua & $\begin{array}{c}\text { Coklat } \\
\text { kehitaman }\end{array}$ & $\begin{array}{c}\text { Coklat } \\
\text { kehitaman }\end{array}$ & $\begin{array}{c}\text { Coklat } \\
\text { kehitaman }\end{array}$ \\
\hline & Bentuk & Kental, & $\begin{array}{l}\text { Kental, } \\
\text { terdapat } \\
\text { endapan }\end{array}$ & $\begin{array}{l}\text { Kental } \\
\text { terdapat } \\
\text { endapan }\end{array}$ & Kental \\
\hline \multirow{3}{*}{ K+ } & Bau & Bau khas & Bau khas & $\begin{array}{c}\text { Tidak } \\
\text { berbau }\end{array}$ & $\begin{array}{c}\text { Tidak } \\
\text { berbau }\end{array}$ \\
\hline & Warna & $\begin{array}{c}\text { Bening } \\
\text { tidak } \\
\text { berwarna }\end{array}$ & $\begin{array}{l}\text { Bening tidak } \\
\text { berwarna }\end{array}$ & $\begin{array}{c}\text { Bening tidak } \\
\text { berwarna }\end{array}$ & $\begin{array}{c}\text { Bening tidak } \\
\text { berwarna }\end{array}$ \\
\hline & Bentuk & Kental & Kental & Kental & Kental \\
\hline \multirow{3}{*}{ K- } & Bau & $\begin{array}{c}\text { Tidak } \\
\text { berbau }\end{array}$ & $\begin{array}{c}\text { Tidak } \\
\text { berbau }\end{array}$ & $\begin{array}{c}\text { Tidak } \\
\text { berbau }\end{array}$ & $\begin{array}{c}\text { Tidak } \\
\text { berbau }\end{array}$ \\
\hline & Warna & $\begin{array}{c}\text { Bening } \\
\text { tidak } \\
\text { berwarna }\end{array}$ & $\begin{array}{c}\text { Bening tidak } \\
\text { berwarna }\end{array}$ & $\begin{array}{c}\text { Bening tidak } \\
\text { berwarna }\end{array}$ & $\begin{array}{c}\text { Bening tidak } \\
\text { berwarna }\end{array}$ \\
\hline & Bentuk & Kental & Kental & Kental & Kental \\
\hline
\end{tabular}

Bentuk sediaan suspensi Kembang Bulan (Tithonia diversifolia A.Gray) dosis 200 $\mathrm{mg} / \mathrm{kgBB}, 300 \mathrm{mg} / \mathrm{kgBB}, 400 \mathrm{mg} / \mathrm{kgBB}$ tersebut relatif konstan berupa sediaan cair kental dan terjadi pembekuan pada suhu $0^{0}$. Warna dan aroma sediaan suspensi sediaan suspensi Kembang Bulan (Tithonia diversifolia A.Gray) dosis $200 \mathrm{mg} / \mathrm{kgBB}, 300$ $\mathrm{mg} / \mathrm{kgBB}, \quad 400 \mathrm{mg} / \mathrm{kgBB}$ tersebut relatif sama berwarna coklat hingga coklat kehitaman dengan aroma yang khas.

Suspensi ekstrak kembang bulan dituangkan kedalam wadah secukupnya kemudian gunakan strip $\mathrm{pH}$ indikator dan amati perubahan warna yang terjadi.

Tabel 6. Data Hasil Pengujian pH

\begin{tabular}{|c|c|c|c|c|c|c|}
\hline Sampel & \multirow{2}{*}{ Suhu } & \multicolumn{4}{|c|}{ Hari ke } & \multirow{2}{*}{ Rata-rata } \\
\hline \multirow{3}{*}{$\mathbf{X}_{1}$} & & 8 & 15 & 22 & 29 & \\
\hline & $0^{\circ} \mathrm{C}$ & 5 & 5 & 5 & 5 & 5 \\
\hline & $25^{\circ} \mathrm{C}$ & 5 & 5 & 5 & 4 & 4,75 \\
\hline
\end{tabular}




\begin{tabular}{|c|c|c|c|c|c|c|}
\hline & $5^{\circ}{ }^{\circ} \mathrm{C}$ & 5 & 6 & 5 & 5 & 5,25 \\
\hline \multirow{3}{*}{$X_{2}$} & $0^{\circ} \mathrm{C}$ & 5 & 5 & 5 & 5 & 5 \\
\hline & $25^{\circ} \mathrm{C}$ & 5 & 5 & 5 & 4 & 4,75 \\
\hline & $5^{\circ}{ }^{\circ} \mathrm{C}$ & 5 & 5 & 5 & 5 & 5 \\
\hline \multirow{3}{*}{$\mathbf{X}_{3}$} & $0^{\circ} \mathrm{C}$ & 5 & 5 & 5 & 5 & 5 \\
\hline & $25^{\circ} \mathrm{C}$ & 5 & 5 & 5 & 6 & 5,25 \\
\hline & $5^{\circ}{ }^{\circ} \mathrm{C}$ & 5 & 5 & 5 & 5 & 5 \\
\hline \multirow{3}{*}{$\mathrm{K}+$} & $0^{\circ} \mathrm{C}$ & 7 & 8 & 8 & 7 & 7,5 \\
\hline & $25^{\circ} \mathrm{C}$ & 8 & 8 & 7 & 7 & 7,5 \\
\hline & $50^{\circ} \mathrm{C}$ & 8 & 8 & 8 & 8 & 8 \\
\hline \multirow{3}{*}{ K- } & $0^{\circ} \mathrm{C}$ & 7 & 7 & 8 & 7 & 7,25 \\
\hline & $25^{\circ} \mathrm{C}$ & 8 & 7 & 8 & 7 & 7,5 \\
\hline & $50^{\circ} \mathrm{C}$ & 8 & 7 & 8 & 8 & 7,75 \\
\hline
\end{tabular}

Pengujian pH suspensi daun Kembang Bulan (Tithonia diversifolia A.Gray) dosis $200 \mathrm{mg} / \mathrm{kgBB}, 300 \mathrm{mg} / \mathrm{kgBB}, 400$ $\mathrm{mg} / \mathrm{kgBB}$ dengan perlakuan suhu $0^{\circ} \mathrm{C}, 25^{\circ} \mathrm{C}$ dan $50^{\circ} \mathrm{C}$ yang dilakukan selama 28 hari dengan rentang waktu pengamatan tiap satu pekan, menunjukkan suspensi memiliki tingkat keasaman relatif sama.
Pengujian kekentalan sediaan suspensi Kembang Bulan (Tithonia diversifolia) dilakukan dengan cara pengambilan sampel sebanyak $5 \mathrm{ml}$ kemudian dimasukkan ke dalam alat viskometer dan diukur dengan menggunakan stopwatch.

Tabel 7. Data hasil uji kekentalan

\begin{tabular}{ccccccc}
\hline \multirow{2}{*}{ Hari $/$ Suhu } & \multicolumn{5}{c}{ Sampel ( Satuan Poise) } \\
\cline { 2 - 7 } & & $\mathbf{X}_{\mathbf{1}}$ & $\mathbf{X}_{\mathbf{2}}$ & $\mathbf{X}_{\mathbf{3}}$ & $\mathbf{K}+$ & K- \\
\hline \multirow{3}{*}{$\mathbf{8}$} & $\mathbf{0}^{\circ} \mathbf{C}$ & 3,19 & 4,18 & 3,34 & 2,42 & 2,09 \\
\cline { 2 - 7 } & $\mathbf{2 5}^{\circ} \mathbf{C}$ & 1,18 & 2,30 & 2.89 & 1,69 & 1,47 \\
\cline { 2 - 7 } & $\mathbf{5 0}^{\circ} \mathbf{C}$ & 1,46 & 1,37 & 2,19 & 2,12 & 1,74 \\
\hline \multirow{3}{*}{$\mathbf{1 5}$} & $\mathbf{0}^{\circ} \mathbf{C}$ & 3,85 & 4,69 & 3,60 & 2,32 & 2,45 \\
\cline { 2 - 7 } & $\mathbf{2 5}^{\circ} \mathbf{C}$ & 0,93 & 2,25 & 2,85 & 1,12 & 1,13 \\
\cline { 2 - 7 } & $\mathbf{5 0}^{\circ} \mathbf{C}$ & 1,83 & 1,94 & 2,01 & 1,32 & 1,10 \\
\hline \multirow{3}{*}{$\mathbf{2 2}$} & $\mathbf{0}^{\circ} \mathbf{C}$ & 3,80 & 4,20 & 3,66 & 2,42 & 2,23 \\
\cline { 2 - 7 } & $\mathbf{2 5}^{\circ} \mathbf{C}$ & 1,04 & 1,15 & 2,06 & 1,2 & 1,07 \\
\cline { 2 - 7 } & $\mathbf{5 0}^{\circ} \mathbf{C}$ & 1,38 & 1,51 & 1,40 & 1,59 & 0,92 \\
\hline \multirow{2}{*}{$\mathbf{2 9}$} & $\mathbf{0}^{\circ} \mathbf{C}$ & 3,87 & 4,48 & 4,85 & 2,29 & 2,13 \\
\cline { 2 - 7 } & $\mathbf{2 5}^{\circ} \mathbf{C}$ & 1,37 & 1,52 & 1,55 & 1,58 & 1,02 \\
\cline { 2 - 7 } & $\mathbf{5 0}^{\circ} \mathbf{C}$ & 1,53 & 1,57 & 1,56 & 1,45 & 1,18 \\
\hline
\end{tabular}

Pengujian dilakukan dengan cara sedimentasi dengan menggunakan jangka sorong sehingga di dapatkan hasil sedimen.

Tabel 8. Data hasil uji sedimentasi

\begin{tabular}{cccccc}
\hline \multirow{2}{*}{ Suhu } & \multirow{2}{*}{ Konsentrasi } & \multicolumn{5}{c}{ Hari ke } \\
\cline { 2 - 6 } & & $\mathbf{8}$ & $\mathbf{1 5}$ & $\mathbf{2 2}$ & $\mathbf{2 9}$ \\
\hline \multirow{3}{*}{$\mathbf{0} \mathbf{C}$} & $\mathbf{X}_{\mathbf{1}}$ & 0,2 & 0,23 & 0,23 & 0,24 \\
\cline { 2 - 6 } & $\mathbf{X}_{\mathbf{2}}$ & 0,37 & 0,31 & 0,39 & 0,41 \\
\cline { 2 - 6 } & $\mathbf{X}_{\mathbf{3}}$ & 0,47 & 0,49 & 0,56 & 0,76 \\
\cline { 2 - 6 } & $\mathbf{K}+$ & 0,09 & 0,1 & 0,15 & 0,17 \\
\cline { 2 - 6 } & $\mathbf{K}-$ & - & - & - & - \\
\hline \multirow{2}{*}{$\mathbf{2 5}^{\circ} \mathbf{C}$} & $\mathbf{X}_{\mathbf{1}}$ & 0,17 & 0,22 & 0,27 & 0,27 \\
\cline { 2 - 6 } & $\mathbf{X}_{\mathbf{2}}$ & 0,23 & 0,28 & 0,28 & 0,39 \\
\hline
\end{tabular}




\begin{tabular}{cccccc}
\hline & $\mathbf{X}_{\mathbf{3}}$ & 0,37 & 0,4 & 0,52 & 0,57 \\
\cline { 2 - 6 } & $\mathbf{K}+$ & 0,13 & 0,11 & 0,13 & 0,14 \\
\cline { 2 - 6 } & $\mathbf{K}-$ & - & - & - & - \\
\hline \multirow{3}{*}{$\mathbf{5 0} \circ \mathbf{C}$} & $\mathbf{X}_{\mathbf{1}}$ & 0,11 & 0,13 & 0,13 & 0,18 \\
\cline { 2 - 6 } & $\mathbf{X}_{\mathbf{2}}$ & 0,2 & 0,26 & 0,23 & 0,32 \\
\cline { 2 - 6 } & $\mathbf{X}_{\mathbf{3}}$ & 0,5 & 0,31 & 0,33 & 0,35 \\
\cline { 2 - 6 } & $\mathbf{K}+$ & 0,11 & 0,13 & 0,15 & 0,17 \\
\cline { 2 - 6 } & $\mathbf{K}-$ & - & - & - & - \\
\hline
\end{tabular}

Dari hasil pengamatan uji sedimentasi, endapan sedimen relatif sama pada suhu $0^{\circ} \mathrm{C}, 25^{\circ} \mathrm{C}, 50^{\circ} \mathrm{C}$ dari dosis $200 \mathrm{mg} / \mathrm{kgBB}, \quad 300 \mathrm{mg} / \mathrm{kgBB}, \quad 400 \mathrm{mg} / \mathrm{kgBB}$, kontrol positif maupun negatif.

Data Hasil Uji Efektivitas Penurunan Kadar Glukosa Darah

Berikut adalah data hasil pengamatan uji efektifitas suspensi ekstrak daun
Kembang Bulan (Tithonia diversifolia A.Gray) terhadap penurunan kadar glukosa darah pada Tikus Putih Jantan yang diinduksi Aloxan. Diperoleh data berdasarkan penurunan kadar glukosa darah yang diambil melalui intra vena dari ekor tikus,Tikus dinyatakan diabetes setelah kadar gula $>126$ mgdl.

Tabel 9. Hasil Pengukuran Kadar Glukosa Darah Pada Tikus Putih Jantan (mg/dl)

\begin{tabular}{|c|c|c|c|c|c|c|c|c|c|}
\hline \multirow[b]{2}{*}{ Perlakuan } & \multirow[b]{2}{*}{ No } & \multirow{2}{*}{$\begin{array}{l}\text { Sebelum } \\
\text { Pemberi } \\
\text { an } \\
\text { Aloxan }\end{array}$} & \multirow{2}{*}{$\begin{array}{c}\text { Setelah } \\
\text { 24jam } \\
\text { Pemberi } \\
\text { an } \\
\text { Aloxan }\end{array}$} & \multicolumn{3}{|c|}{ Setelah perlakuan } & \multirow[b]{2}{*}{$\begin{array}{c}\text { Rata- } \\
\text { rata } \\
\text { ekstrak }\end{array}$} & \multirow[b]{2}{*}{$\begin{array}{c}\text { Penurunan } \\
\text { kadar }\end{array}$} & \multirow[b]{2}{*}{$\begin{array}{l}\text { Presentase } \\
\text { penurunan }\end{array}$} \\
\hline & & & & $\begin{array}{l}\text { Hari } \\
\text { ke-7 }\end{array}$ & $\begin{array}{c}\text { Hari } \\
\text { ke- } \\
14\end{array}$ & $\begin{array}{c}\text { Hari } \\
\text { ke- } \\
21\end{array}$ & & & \\
\hline \multirow[t]{3}{*}{$\mathrm{X} 1$} & 1 & 58 & 220 & 149 & 82 & 69 & \multirow[b]{3}{*}{126,44} & \multirow[b]{3}{*}{87,89} & \multirow[b]{3}{*}{$44 \%$} \\
\hline & 2 & 78 & 218 & 215 & 168 & 101 & & & \\
\hline & 3 & 80 & 205 & 147 & 108 & 99 & & & \\
\hline \multicolumn{2}{|l|}{ Rata-rata } & 72 & 214,33 & $\begin{array}{c}170 \\
33\end{array}$ & $\begin{array}{c}119 \\
33\end{array}$ & $\begin{array}{l}89 \\
67\end{array}$ & & & \\
\hline \multirow[t]{3}{*}{$\mathrm{X} 2$} & 1 & 82 & 303 & 148 & 88 & 80 & \multirow{4}{*}{115,33} & \multirow{4}{*}{190,33} & \multirow{4}{*}{$62,3 \%$} \\
\hline & 2 & 69 & 341 & 171 & 107 & 82 & & & \\
\hline & 3 & 57 & 273 & 179 & 104 & 79 & & & \\
\hline \multicolumn{2}{|c|}{ Rata-rata } & 69,33 & 305,67 & 166 & $\begin{array}{l}99 \\
67\end{array}$ & $\begin{array}{l}80 \\
33\end{array}$ & & & \\
\hline \multirow[t]{3}{*}{$\mathrm{X} 3$} & 1 & 79 & 559 & 385 & 154 & 81 & \multirow{4}{*}{158,78} & \multirow{4}{*}{273,22} & \multirow{4}{*}{$63,2 \%$} \\
\hline & 2 & 61 & 366 & 199 & 115 & 91 & & & \\
\hline & 3 & 91 & 371 & 189 & 112 & 103 & & & \\
\hline \multicolumn{2}{|c|}{ Rata-rata } & 77 & 432 & $\begin{array}{c}257 \\
67\end{array}$ & 127 & $\begin{array}{l}91 \\
67\end{array}$ & & & \\
\hline \multirow[t]{3}{*}{$\mathrm{K}^{+}$} & 1 & 78 & 332 & 220 & 129 & 82 & \multirow{4}{*}{143,11} & \multirow{4}{*}{189,84} & \multirow{4}{*}{$57 \%$} \\
\hline & 2 & 49 & 397 & 218 & 132 & 85 & & & \\
\hline & 3 & 66 & 270 & 205 & 116 & 101 & & & \\
\hline \multicolumn{2}{|c|}{ Rata-rata } & 64,33 & 333 & $\begin{array}{c}214 \\
33\end{array}$ & $\begin{array}{c}125 \\
67\end{array}$ & $\begin{array}{l}89 \\
33 \\
\end{array}$ & & & \\
\hline \multirow[t]{3}{*}{$\mathrm{K}^{-}$} & 1 & 81 & 292 & 397 & 366 & 273 & \multirow{4}{*}{379,33} & \multirow{4}{*}{$-51,66$} & \multirow{4}{*}{$-15,7 \%$} \\
\hline & 2 & 98 & 238 & 447 & 383 & 292 & & & \\
\hline & 3 & 47 & 453 & 476 & 397 & 383 & & & \\
\hline Rata rata & & 75,33 & 327,67 & 440 & 382 & 316 & & & \\
\hline
\end{tabular}


Keterangan

X1 :Suspensi ekstrak daun kembang bulan dosis $200 \mathrm{mg} / \mathrm{kgBB}$

$\mathrm{X} 2$ : Suspensi ekstrak daun kembang bulan dosis $300 \mathrm{mg} / \mathrm{kgBB}$

$\mathrm{X} 3$ : Suspensi ekstrak daun kembang bulan dosis $400 \mathrm{mg} / \mathrm{kgBB}$

$\mathrm{K} 1$ : Acarbose yang disuspensikan

K2 : Suspensi CMC $1 \%$

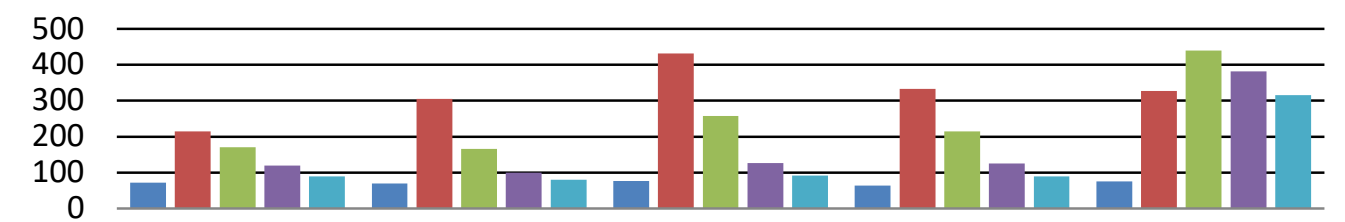

Suspensi Ekstrak Suspensi Ekstrak Suspensi Ekstrak Kontrol Positif Kontrol Negatif

Daun Kembang Daun Kembang Daun Kembang

Bulan Dosis Bulan Dosis Bulan Dosis

$200 \mathrm{mg} / \mathrm{kgBB} \quad 300 \mathrm{mg} / \mathrm{kgBB} \quad 400 \mathrm{mg} / \mathrm{kgBB}$

Sebelum Induksi $\square$ Sesudah Induksi Aloxan Hari ke 7 Hari ke 14 Hari ke 21

\section{Analisa Data}

Dalam perhitungan data statistik menunjukan bahwa terdapat perbedaan penurunan kadar glukosa darah pada tikus putih jantan dengan dosis yang berbeda. Jika hasil fhitung>ftabel, maka $\mathrm{H}$ ditolak dan $\mathrm{H} 1$ diterima. Hipotesis yang diajukan adalah :

$\mathrm{H}_{0}$ : Suspensi ekstrak Daun Kembang Bulan

(Tithonia diversifolia A.Gray) tidak efektif menurunkan kadar glukosa darah pada tikus putih jantan.

$\mathrm{H}_{1}$ : Suspensi ekstrak Daun Kembang Bulan

(Tithonia diversifolia A.Gray) tidak efektif menurunkan kadar glukosa darah pada tikus putih jantan.

Untuk langkah awal uji anava satu arah dilakukan Uji Normalitas. Data dikatakan normal jika (sig) >0,05. 0,05 didapat dari taraf keyakinan untuk analisa data.

\section{Uji Normalitas Data (Tests of Normality)}

Untuk uji normalitas dengan hipotesis sebagai berikut:

$\mathrm{H}_{0}$ : Data penurunan kadar glukosa darah antar kelompok setelah perlakuan tidak terdistribusi normal.

$\mathrm{H}_{1}$ : Data penurunan kadar glukosa darah antar kelompok setelah perlakuan terdistribusi normal.

Berdasarkan tabel diatas, dengan tingkat kepercayaan $\alpha=0,05$ diperoleh nilai signifikansi (Sig) pada uji Kolmogorov Smirnov X1 $(0,566>0,05), X 2(0,273>0,05$ ), $\mathrm{X} 3(0,360>0,05), \mathrm{K}+(0,433>0,05), \mathrm{K}-$
$(0,619>0,05)$ artinya $\mathrm{H}_{1}$ diterima maka data kelompok terdistribusi normal.

Kemudian setelah data berdistribusi normal dilanjutkan dengan uji homogenitas, karena akan menentukan langkah analisis selanjutnya jika data homogen maka data bisa dianalisis dengan uji anava,untuk kriteria data homogen yaitu sama dengan uji normalitas yaitu jika nilai (sig) >0,05.

\section{Uji Homogenitas Data (Tests of Homogeneity)}

Untuk uji homogenitas dengan hipotesis sebagai berikut :

$\mathrm{H}_{0}$ : Data penurunan kadar glukosa darah antar kelompok setelah perlakuan tidak bervariasi homogen.

$\mathrm{H}_{1}$ : Data penurunan kadar glukosa darah antar kelompok setelah perlakuan bervariasi homogen.

Berdasarkan hasil uji homogenitas diperoleh nilai (sig) $>0,05, \quad(0,059>0,05)$. Berarti data yang diperoleh homogen. Setelah data yang diperoleh berdistribusi normal dan homogen maka dilanjutkan dengan menganalisis dengan uji anava 1 arah.

\section{Uji ANOVA Satu Arah}

$\mathrm{H}_{0}$ : Suspensi ekstrak daun Kembang Bulan (Tithonia diversifolia A.Gray) tidak efektif menurunkan kadar glukosa darah pada tikus putih jantan.

$\mathrm{H}_{1}$ : Suspensi ekstrak daun Kembang Bulan (Tithonia diversifolia A.Gray) efektif menurunkan kadar glukosa darah pada tikus putih jantan. 
Berdasarkan hasil dari perhitungn uji anova satu arah diperoleh hasil (fhitung) pada table sebesar 5,529 dan $f$ tabel sebesar 3,59. Jadi $(5,529>3,59)$, artinya Ho ditolak dan $\mathrm{H}_{1}$ diterima, sehingga dapat disimpulkan bahwa suspensi ekstrak suspensi ekstrak daun Kembang Bulan (Tithonia diversifoliaA.Gray) efektif menurunkan kadar glukosa darah pada tikus putih jantan.

\section{Test (Paired Sample Test)}

Uji $t-$ Test digunakan untuk menghitung statistik $t$ dan relevansi statistik ditafsirkan menggunakan distribusi $t$ (dengan jumlah derajat kebebasan yang sesuai). Uji $t$ - Test dapat melihat perbandingan dua kelompok data saja. (Ridwan, 2003)

Untuk uji $t$-Test, dalam penelitian ini menggunakan Paired Sample Test. Dengan hipotesis :

$\mathrm{H}_{0}$ : Tidak ada perbedaan efektivitas Suspensi ekstrak daun Kembang Bulan (Tithonia diversifolia A.Gray) pada penurunan kadar glukosa darah dengan kontrol positif

$\mathrm{H}_{1}$ : Adanya perbedaan efektivitas Suspensi ekstrak daun Kembang Bulan (Tithonia diversifolia A.Gray) pada penurunan kadar glukosa darah dengan kontrol positif.

Berdasarkan dari perhitungan uji tTest diperoleh semua nilai thitung lebih kecil dari t tabel, sehingga $t$ hitung $<\mathrm{t}$ tabel $(-$ $1,932<3,599), \quad(-3,227<3,599)$, $(1,532<3,599)$, Maka H0 diterima dan H1 ditolak, artinya Tidak ada perbedaan efektivitas Suspensi ekstrak Kembang Bulan (Tithonia diversifolia A.Gray) pada penurunan kadar glukosa darah dengan kontrol positif.

\section{PEMBAHASAN}

Proses penelitian meliputi determinasi tanaman Kembang Bulan (Tithonia diversifolia A.Gray), pembuatan simplisia, pembuatan ekstrak kental ,pembuatan suspensi ekstrak daun Kembang Bulan pada dosis $200 \mathrm{mg} / \mathrm{kgBB}, 300$ $\mathrm{mg} / \mathrm{kgBB}, 400 \mathrm{mg} / \mathrm{kgBB}$, dan uji efektivitas penurunan kadar glukosa darah. Dilakukan terlebih dahulu determinasi tanaman Kembang Bulan (Tithonia diversifolia A.Gray), determinasi dilakukan di laboratorium Herbarium Bandungense SITH ITB, tujuan determinasi tanaman Kembang Bulan, adalah untuk memastikan dan meyakinkan bahwa tanaman yang digunakan benar-benar tanaman Kembang Bulan (Tithonia diversifolia A.Gray). Bagian tanaman yang digunakan dalam penelitian ini adalah daun Kembang Bulan yang berasal dari Cirebon, Jawa Barat. Kemudian Penyarian ekstrak Kembang Bulan (Tithonia diversifolia A.Gray) dilakukan dengan menggunakan metode maserasi. daun Kembang Bulan segar dicuci bersih dan dikeringkan diletakkan diatas tampar kemudian diangin-angin di dalam ruangan sampai kering. Kembang Bulan (Tithonia diversifolia A.Gray) yang sudah kering dimasukkan ke dalam alat penghancur (blender) dan ditimbang seberat 250 gram diberi alkohol 70\% sebanyak 2,5 liter, lalu dicampur. Maserasi selama 7 hari, kemudian disaring dengan menggunakan kain flannel. Setelah itu didapatkan hasil ekstrak. Setelah ekstrak diperoleh kemudian pembuatan suspensi ekstrak biji Kembang Bulan (Tithonia diversifolia A.Gray) terlebih dahulu dilakukan pembuatan larutan suspending agent dengan CMC Na 1\%. Pembuatan suspensi ekstrak Kembang Bulan (Tithonia diversifolia A.Gray) dengan berbagai dosis yaitu dosis $200 \mathrm{mg} / \mathrm{kgBB}, 300 \mathrm{mg} / \mathrm{kgBB}, 400$ $\mathrm{mg} / \mathrm{kgBB}$. Masing-masing dosis suspensi ekstrak daun Kembang Bulan (Tithonia diversifolia A.Graydibuat sebanyak $200 \mathrm{ml}$ dengan menggunakan pensuspensi CMC, pengawet Nipagin $0,1 \%$ dan pelarut Aquadest. Dalam formulasi ini, pembuatan suspensi dilakukan agar didapat sediaan yang lebih stabil. Pada pembuatan suspensi ada beberapa karakteristik suspensi, baik fase dispersi maupun terdispersi. Hal ini dimaksudkan agar obat mudah terpenetrasi oleh pembawa dan tidak menggumpal atau terapung pada pembawa (5).

Setelah suspensi selesai dibuat menjadi beberapa wadah, kemudian dilakukan pengujian stabilitas suspensi dengan perlakuan pada suhu $0^{\circ} \mathrm{C}, 25^{\circ} \mathrm{C}$ dan $50^{\circ} \mathrm{C}$ dengan melakukan uji organoleptis, uji $\mathrm{pH}$, uji kekentalan uji sedimentasi, dan uji efektivitas.

Uji organoleptis dilakukan dengan indera penglihatan, peraba dan penciuman dengan mengamati bentuk, warna dan bau. Hasil pengamatan organoleptis bentuk pada suspensi Kembang Bulan (Tithonia diversifolia A.Gray) dosis $200 \mathrm{mg} / \mathrm{kgBB}, 300$ 
$\mathrm{mg} / \mathrm{kgBB}, 400 \mathrm{mg} / \mathrm{kgBB}$ dengan perlakuan suhu $0^{\circ} \mathrm{C}, 25^{\circ} \mathrm{C}$ dan $50^{\circ} \mathrm{C}$ yang dilakukan selama 28 hari dengan rentang waktu pengamatan tiap satu pekan diketahui bahwa bentuk sediaan suspensi Kembang Bulan (Tithonia diversifolia A.Gray) dosis 200 $\mathrm{mg} / \mathrm{kgBB}, 300 \mathrm{mg} / \mathrm{kgBB}, 400 \mathrm{mg} / \mathrm{kgBB}$ tersebut relatif konstan berupa sediaan cair kental dan terjadi pembekuan pada suhu $0^{\circ}$.

Organoleptis warna suspensi daun Kembang Bulan (Tithonia diversifolia A.Gray) dosis $200 \mathrm{mg} / \mathrm{kgBB}, 300 \mathrm{mg} / \mathrm{kgBB}, 400$ $\mathrm{mg} / \mathrm{kgBB}$ dengan perlakuan suhu $0^{\circ} \mathrm{C}, 25^{\circ} \mathrm{C}$ dan $50^{\circ} \mathrm{C}$ yang dilakukan selama 28 hari dengan rentang waktu pengamatan tiap satu pekan diketahui konstan hitam kecoklatan.

Organoleptis bau suspensi daun Kembang Bulan (Tithonia diversifolia A.Gray) dosis $200 \mathrm{mg} / \mathrm{kgBB}, 300 \mathrm{mg} / \mathrm{kgBB}, 400$ $\mathrm{mg} / \mathrm{kgBB}$ dengan perlakuan suhu $0^{\circ} \mathrm{C}, 25^{\circ} \mathrm{C}$ dan $50^{\circ} \mathrm{C}$ yang dilakukan selama 28 hari dengan rentang waktu pengamatan tiap satu pekan diketahui konstan aroma khas dari daun Kembang Bulan.

Pengujian pH suspensi daun Kembang Bulan (Tithonia diversifolia A.Gray) dosis $200 \mathrm{mg} / \mathrm{kgBB}, 300 \mathrm{mg} / \mathrm{kgBB}, 400$ $\mathrm{mg} / \mathrm{kgBB}$ dengan perlakuan suhu $0^{\circ} \mathrm{C}, 25^{\circ} \mathrm{C}$ dan $50^{\circ} \mathrm{C}$ yang dilakukan selama 28 hari dengan rentang waktu pengamatan tiap satu pekan diketahui konstan yang menunjukkan suspensi memiliki tingkat keasaman stabil atau batas normal yang relatif sama.

Dari hasil Uji stabilitas suspensi tersebut dapat disimpulkan bahwa suspensi dapat dikatakan stabil karena dari tiap-tiap perlakuan suhu $0^{\circ} \mathrm{C}, 25^{\circ} \mathrm{C}$ dan $50^{\circ} \mathrm{C}$ suspensi tidak terjadi perubahan yang signifikan baik dari organoleptis bau, bentuk maupun warna dan juga uji $\mathrm{pH}$.

Berdasarkan hasil pengukuran penurunan kadar glukosa darah pada tikus putih jantan setelah perlakuan selama 21 hari dapat diketahui bahwa suspensi ekstrak daun Kembang Bulan pada dosis 200 $\mathrm{mg} / \mathrm{kgBB}$ memiliki rata-rata $126,44 \mathrm{mg} / \mathrm{dl}$ dengan penurunan sebanyak $87,89 \mathrm{mg} / \mathrm{dl}$, sehingga didapat presentase penurunan sebesar 44\%. Pada suspensi ekstrak daun Kembang Bulan pada dosis $300 \mathrm{mg} / \mathrm{kgBB}$ memiliki rata-rata $115,33 \mathrm{mg} / \mathrm{dl}$ dengan penurunan sebanyak $190 \mathrm{mg} / \mathrm{dl}$, sehingga didapat presentase penurunan sebesar $62,3 \%$. Pada suspensi ekstrak daun Kembang
Bulan pada dosis $400 \mathrm{mg} / \mathrm{kgBB}$ memiliki rata-rata $158,78 \mathrm{mg} / \mathrm{dl}$ dengan penurunan sebanyak 273,22 mg/dl, sehingga didapat presentase penurunan sebesar $63,2 \%$. Pada Kontrol Positif yaitu Acarbose yang disuspensikan dengan dosis $9 \mathrm{mg} / \mathrm{kgBB}$ memiliki rata-rata $143,11 \mathrm{mg} / \mathrm{dl}$ dan penurunan sebanyak $189,84 \mathrm{mg} / \mathrm{dl}$, sehingga didapat presentase penurunan sebesar $57 \%$. Pada Kontrol Negatif yaitu suspensi CMC 1\% memiliki rata-rata $379,33 \mathrm{mg} / \mathrm{dl}$ dan peningkatan sebanyak $51,66 \mathrm{mg} / \mathrm{dl}$ sehingga menghasilkan presentase kenaikan sebesar $15,7 \%$. Dilihat dari presentase penurunan kadar glukosa darah, bila dibandingkan dengan kontrol positif yaitu acarbose, suspensi ekstrak daun Kembang Bulan dengan dosis 300 dan $400 \mathrm{mg} / \mathrm{kgBB}$ lebih efektif menurunkan kadar glukosa darah. Pada kontrol negatif terdapat kenaikan kadar glukosa darah yang mungkin disebabkan rusaknya sel $\beta$ - pankreas oleh aloxan secara permanen.

Sumber lain yang mengacu pada penelitian tentang ekstrak daun Kembang Bulan sebagai antidiabetik diantaranya; (6) Penelitian yang dilakukan sebelumnya menyatakan bahwa Infusa daun Kembang Bulan dapat menurunkan kadar glukosa darah pada tikus putih yang diinduksi aloxan dengan efek antihiperglikemik yang mendekati metformin. (7) Hasil penelitian menyatakan bahwa dosis ekstrak etanol Tithonia diversifolia A.Gray $77 \mathrm{mg} / \mathrm{kgBB}$ pada tikus putih memiliki efek antihiperglikemik yang mendekati acarbose sebagai kontrol positif. (8) Hasil penelitian menyatakan pada dosis $14 \mathrm{mg} / \mathrm{kgBB}$ ekstrak etanol Kembang Bulan dapat menurunkan jumlah sel raksasa pada pankreas, hal ini menunjukkan bahwa daun Kembang Bulan dapat menurunkan kadar glukosa darah dengan cara menurunkan efek radikal bebas dari aloxan. Efek penurunan kadar glukosa darah dari suspensi ekstrak daun Kembang Bulan disebabkan oleh senyawa flavonoid dan alkaloid yang berfungsi sebagai antioksidan yang memicu regenerasi sel $\beta$-pankreas, dan saponin yang berfungsi meningkatkan sensitivitas insulin di jaringan adiposa.

Pada penelitian kandungan Kembang Bulan lainnya yang dilakukan oleh Amanatie dan menunjukkan bahwa ekstrak air daun Kembang Bulan (Tithonia diversifolia A.Gray) 
positif mengandung flavonoid, alkaloid, dan tanin. (4) Penelitian yang dilakukan sebelumnya menyatakan bahwa dari isolasi flavonoid daun Kembang Bulan (Tithonia diversifolia A.Gray) didapatkan senyawa flavon yang mengandung gugus 4'-hidroksi dan 4',7-dihidroksi yang mampu meregenerasi sel $\beta$-pankreas.

Setelah hasilnya diperoleh, maka hasil tersebut dianalisis dengan SPSS versi 21 menggunakan uji normalitas, uji homogenitas, dan uji t satu sampel.Dari hasil analisa, diketahui bahwa data tersebut berdistribusi normal dan homogen, dan diketahui bahwa kadar glukosa darah awal berbeda signifikan dengan data kadar glukosa darah setelah pemberian aloxan, dan menurut hasil uji $\mathrm{t}$ satu sampel diperoleh kadar glukosa darah pada dosis 200 $\mathrm{mg} / \mathrm{kgBB}, 300 \mathrm{mg} / \mathrm{kgBB}$, dan $400 \mathrm{mg} / \mathrm{kgBB}$ tidak terdapat perbedaan dengan kontrol positif (acarbose $9 \mathrm{mg} / \mathrm{kgBB}$ ).

Perbedaan signifikan antara data pengambilan darah pertama dan data pengambilan data darah kedua mengindikasikan bahwa aloxan telah menyebabkan kenaikan kada glukosa darah,sedangkan perbedaan antara pengambilan data pengambilan darah kedua dan data pengambilan darah ketiga ataupun data pengambilan darah keempat dan kelima mengindikasikan bahwa terjadi penurunan kadar glukosa darah setelah pemberian suspensi ekstrak Kembang Bulan (Tithonia diversifolia A.Gray), dan kontrol positif (acarbose).

\section{SIMPULAN}

Terdapat penurunan kadar glukosa darah secara signifikan pada pemberian suspensi ekstrak daun Kembang Bulan (Tithonia diversifolia A.Gray)dengan dosis $200 \mathrm{mg} / \mathrm{kgBB}, \quad 300 \mathrm{mg} / \mathrm{kgBB}, \quad$ dan $400 \mathrm{mg} / \mathrm{kgBB}$ dengan persentase $44 \%$, $62,3 \%$, dan $63,2 \%$, sehingga dapat dijadikan obat anti diabetes. Tidak ada perbedaan signifikan diantara ketiga dosis, sehingga dosis yang efektif adalah dosis dengan presentase terendah yaitu $200 \mathrm{mg} / \mathrm{kgBB}$.
Suspensi ekstrak daun Kembang Bulan pada dosis $\quad 200 \mathrm{mg} / \mathrm{kgBB}, \quad 300 \mathrm{mg} / \mathrm{kgBB}$, $400 \mathrm{mg} / \mathrm{kgBB}$, kontrol positif dan kontrol negatif relatif stabil pada semua suhu.

\section{DAFTAR PUSTAKA}

1. Depkes RI. Pharmaceutical Care Untuk Penyakit Diabetes Mellitus. Jakarta: Departemen Kesehatan Republik Indonesia; 2005.

2. Department of Noncommunicable Disease Surveillance. Definition, Diagnosis and Classification of Diabetes Mellitus and its Complications. Geneva: WHO; 1999.

3. Rudy Bilous dan Richard Donelly. Buku Pegangan Diabetes Edisi ke 4. Jakarta: Bumi Medika; 2015.

4. Widari, M. Isolasi Senyawa Flavonoid Dari Daun Kembang Bulan (Tithonia diversifolia). Medan: Departemen Farmasi FMIPA USU; 2005. Hal 43

5. Allen Loyd V, Popovich Nicholas G, Ansel Howard C. Bentuk Sediaan Farmasetis \& Sistem Penghantaran Obat. Jakarta: Penerbit Buku Kedokteran EGC; 2014.

6. Agung Prasetyo, Tiara Grhanesia Denashurya, Widiayu Sekar Putri, Muhammad In'am Ilmiawan. Perbandingan Efek Hipoglikemik Infusa Daun Kembang Bulan (Tithonia diversifolia A. Gray) dan Metformin pada Tikus yang Diinduksi Aloksan. Pontianak : Program Studi Pendidikan Dokter Fakultas Kedokteran Universitas Tanjungpura; 2016.

7. Ary Rizki Darmawi, Chairul Saleh, Rudi Kartika. Aktifitas Antihiperglikemik Dari Ekstrak Etanol dan n-Heksana Daun Kembang Bulan (Tithonia diversifolia A.Gray) Pada Tikus Jantan. Program Studi Kimia, Fakultas MIPA Universitas Mulawarman; 2015.

8. Ronald Pasaribu, Salomo Hutahaean, dan Syafruddin Ilyas. Uji Antihiperglikemia Ekstrak Etanol Daun Kembang Bulan (Tithonia diversifolia) Pada Mencit (Mus musculus) Yang Diinduksi Dengan Aloxan. Departemen Biologi, Fakultas MIPA Universitas Sumatera Utara; 2015. 